\title{
Comparative Analysis between Bare Frame, Infill Frame and Braced Frame with Soft Storey
}

\author{
R.M. Vinayak and Yogeendra R. Holebagilu
}

\begin{abstract}
Masonry infill is used to increase initial stiffness and strength of reinforced concrete (RC) frame buildings. Steel bracings are used to resist lateral loads and lateral deflection hence control the damage caused by the earthquake. In some cities of India the first storey of the RC frame building open to generate parking space called open ground storey also termed as Soft storey. In this study, response spectrum analysis is carried out for bare frame, masonry infill frame and braced frame. A symmetrical frame building $(\mathrm{G}+5)$ located in seismic zone- $\mathrm{V}$ is considered for modeling of all 3 frames for all 3 type of soils. Modeling of infill is considered by "Equivalent diagonal strut method". Eccentric forward and reverse steel bracing is used for modeling of braced frame.
\end{abstract}

Comparative study concludes that the masonry infill frames are best suited among all the three types of constructions in terms of material cost benefit added with better seismic behavior. Response Spectrum method is used for seismic analysis. ETAB 2015 software is used and results are compared.

Keywords--- Soft Storey, Masonry Infill, Equivalent Diagonal Strut Method, Braced Frame, Response Spectrum Analysis, Etabs.

\section{INTRODUCTION}

$\mathrm{E}$ ARTHQUAKE is nothing but a shaking of ground, caused by volcanic activity or movement around geologic errors. The most important point is to construct a building structure that can resist the seismic loads efficiently or not. So to overcome the problem of earthquake research study has been made on the different structural arrangement to find out the most optimized solution to produce an efficient safe earthquake resistant building.

Most of urban multistory buildings in our country today have kept ground storey open as bound to happen. Primarily to procreate parking or social works the open first storey of reinforced concrete frame building is kept space. It's been known that the masonry infill walls dispose the rigidity \& strength of infill frame structures.
The bracings are highly efficient in being able to produce very stiff structures laterally for a minimum of additional material. Bracing has been used to stabilize laterally the majority of the tallest building structure as well as one of the major retrofit measures.

The buildings with open ground storey such as ground storey being open spaces for parking or some other purposes, special arrangements must be made to increase the lateral strength and stiffness of the open ground storey. It is known that for Equivalent Static Analysis, seismic mass of the whole structure resonates with a single time period and the structure is assumed to be in its fundamental mode of vibration. Whereas in Response Spectrum Analysis multiple modes of responses can be considered and this attempt is mandatory in most of the building codes excluding for very complex or simple structure.

\section{PROJECT DESCRIPTION}

In this work, analysis has been made to find the individual effect of (Model-1) RC bare frame, (Model-2) RC frame with infill, (Model-3) RC frame with Diagonal bracing, for multi-storey building of $\mathrm{G}+5$ floors.

\section{A. Modeling}

In this study, 3 types of $(\mathrm{G}+5)$ storey RC buildings with the hard, medium \& soft soil are prepared and analyzed to know the response of buildings during earthquake. The height of the building is $25 \mathrm{~m}$ and size is $16 \mathrm{~m}$ x $12 \mathrm{~m}$. The supports are assumed to be restrained at the ground level. Response spectrum analysis is used

\section{B. Model Configuration}

3 types of model configuration considered for study in the hard, medium \& soft soil are as follows

1. G+5 RC Bare Framed structure

2. G+5 RC Framed structure with Infill

3. G+5 RC Framed structure with Bracing

R.M. Vinayak., PG Student, Department of Civil Engineering, Government Engineering College, HAVERI, Karnataka, India. E-mail:vrmvinayak277@gmail.com

Yogeendra R. Holebagilu, Assistant Professor, Department of Civil Engineering, Government Engineering College, Haveri, Karnataka, India. DOI:10.9756/BIJMMI.8160 


\section{Building Description}

Table 1: Building Description

\begin{tabular}{|l|l|l|}
\hline Sl. No. & Description & Data \\
\hline 1 & Number of Stories & 6 \\
\hline 2 & The building Frame system & SMRF \\
\hline 3 & Building Use & Commercial \\
\hline 4 & Floor Height & 4 meter \\
\hline \multirow{3}{*}{5} & \multirow{3}{*}{ Types of soil } & Hard \\
\cline { 3 - 3 } & & Medium \\
\cline { 3 - 3 } & & Soft \\
\hline 6 & Support Condition & Fixed \\
\hline Material Properties & M25 \\
\hline 7 & Grade of Concrete & Fe 415 \\
\hline 8 & Grade of Steel & $5000 \sqrt{\mathrm{fck}}$ \\
\hline 9 & Young's modules of Concrete & $25 \mathrm{kN} / \mathrm{m}^{3}$ \\
\hline 10 & Density of Concrete & $18 \mathrm{kN} / \mathrm{m}^{3}$ \\
\hline 11 & Density of Masonry & 0.2 \\
\hline 12 & Poisson's ratio & \\
\hline Structural Members & $300 \mathrm{~mm} \times 700 \mathrm{~mm}$ \\
\hline 13 & Column Size & $300 \mathrm{~mm} \times 500 \mathrm{~mm}$ \\
\hline 14 & Beam Size & $230 \mathrm{~mm}$ \\
\hline 15 & Thickness of Wall & $140 \mathrm{~mm}$ \\
\hline 16 & Thickness of Slab &
\end{tabular}

\section{METHOD OF ANALYSIS}

In present work Response Spectrum Method is used for analysis. The analysis of infill frame is carried out by Equivalent Diagonal Strut Method. The frames are analyzed with static loads for RCC sections for beams and columns using IS 456. IS 1893-2002 part1 is used for both static and dynamic analysis. All frames are analyzed separately by using Response Spectrum Method by using software ETABS 2015.

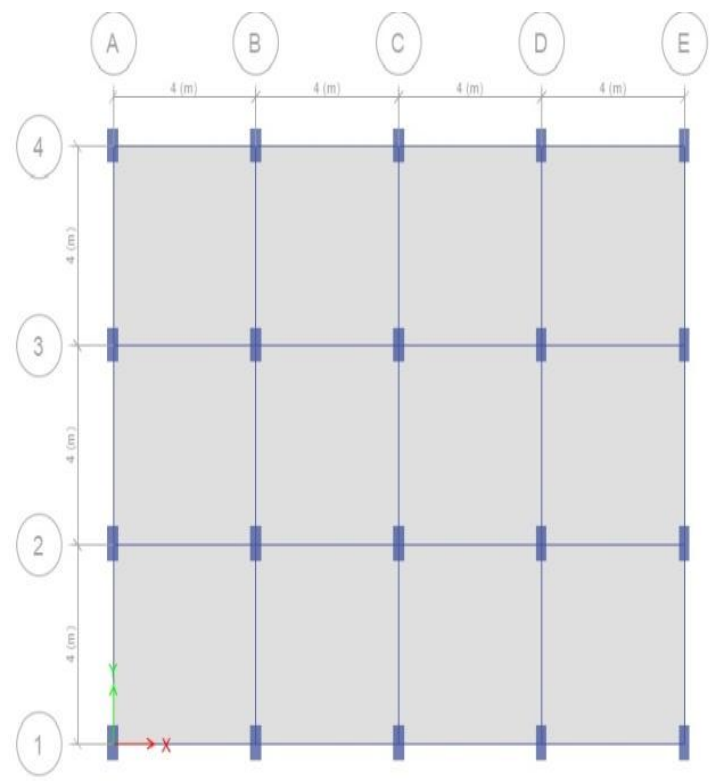

Figure 1: RC Frame Model Plan

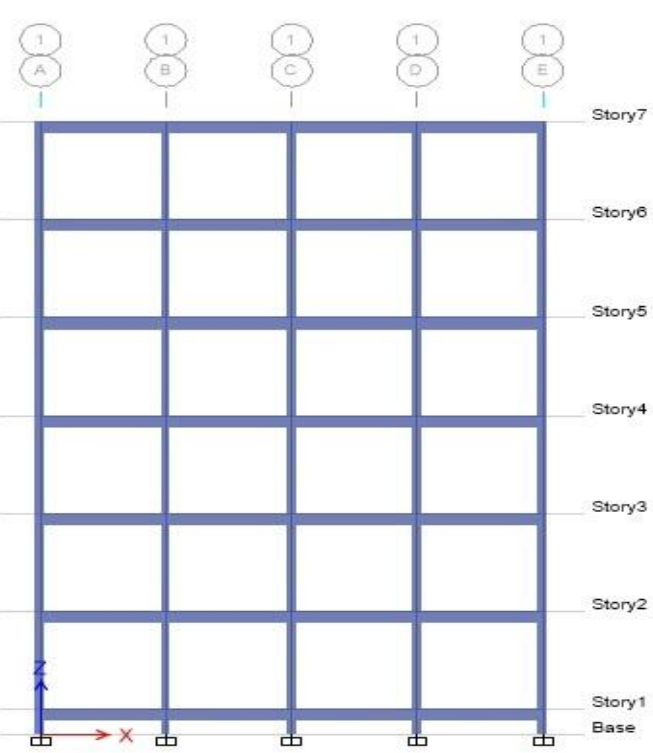

Figure 2: RC Bare Frame Model of Elevation

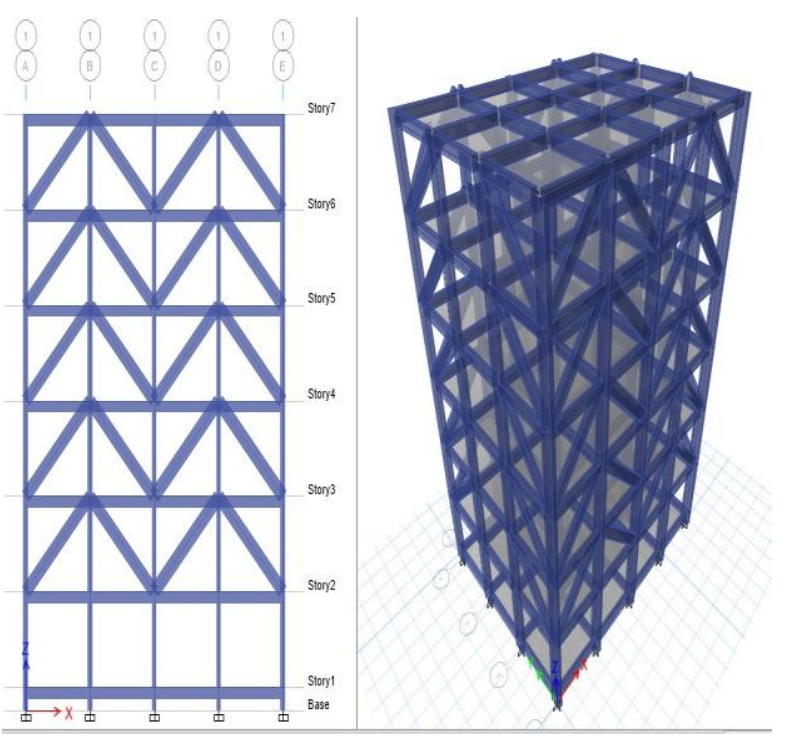

Figure 3: RC Frame Model of Building with Masonry Strut

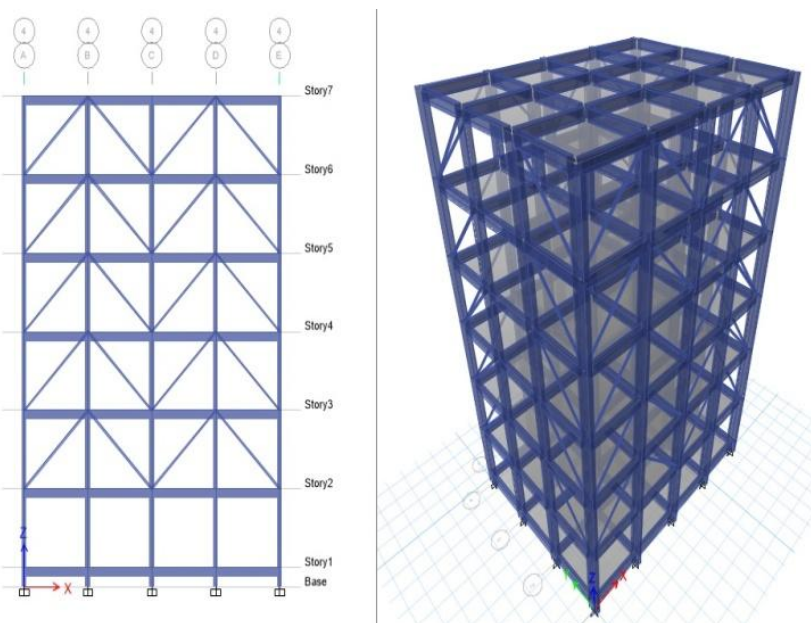

Figure 4: RC Frame Model of Building with Bracing 


\section{RESULTS AND DISCUSSION}

This project is carried out to compare the responses of bare frame, RC frame with strut and RC frame with Diagonal bracing for multi-storey building of G+ 5 floors. Totally 9 models are taken for analyses. The linear dynamic (Response spectrum) analysis is performed for zone $\mathrm{V}$ for different soil stratum. The structural responses like base shear, mode period, storey acceleration, storey displacement, storey drifts are compared. Modelling and analysis are carried out by using ETABS 2015 software.

Table 2: Base Shear in Different Soil

\begin{tabular}{|c|c|c|c|}
\hline \multirow{2}{*}{ Soil type } & \multicolumn{3}{|c|}{ Base shear $(\mathrm{kN})$ in different soils } \\
\cline { 2 - 4 } & Bare & Bracing & Masonry strut \\
\hline Hard & 2263.107 & 2265.546 & 2314.322 \\
\hline Medium & 3077.826 & 3081.143 & 3188.374 \\
\hline Soft & 3185.324 & 3188.756 & 3299.841 \\
\hline
\end{tabular}

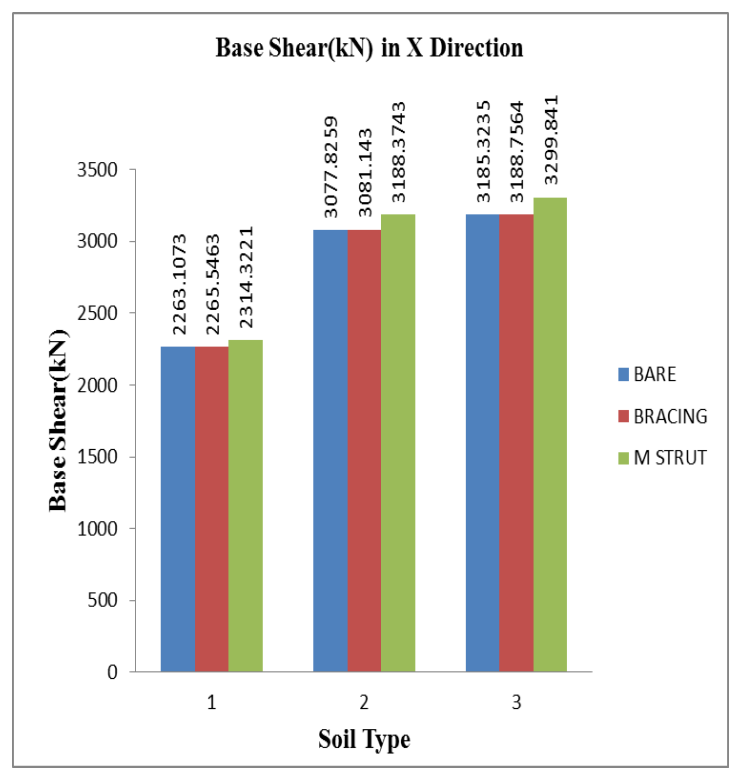

Figure 5: Base Shear in Different Soil

Base shear increases with decrease in the stiffness of the soil. As the stiffness of the soil reduces shear resistance at the base of the structure reduces. Compared to braced frame structure masonry infill structure will have high base shear due to increase in the seismic weight in the structure.

Table 3: Time Period (sec)

\begin{tabular}{|c|c|c|c|}
\hline \multirow{2}{*}{ Soil type } & \multicolumn{3}{|c|}{ Time period (sec) } \\
\cline { 2 - 4 } & Bare & Bracing & Masonry strut \\
\hline Hard & 1.914 & 1.373 & 1.284 \\
\hline Medium & 1.914 & 1.373 & 1.284 \\
\hline Soft & 1.914 & 1.373 & 1.284 \\
\hline
\end{tabular}

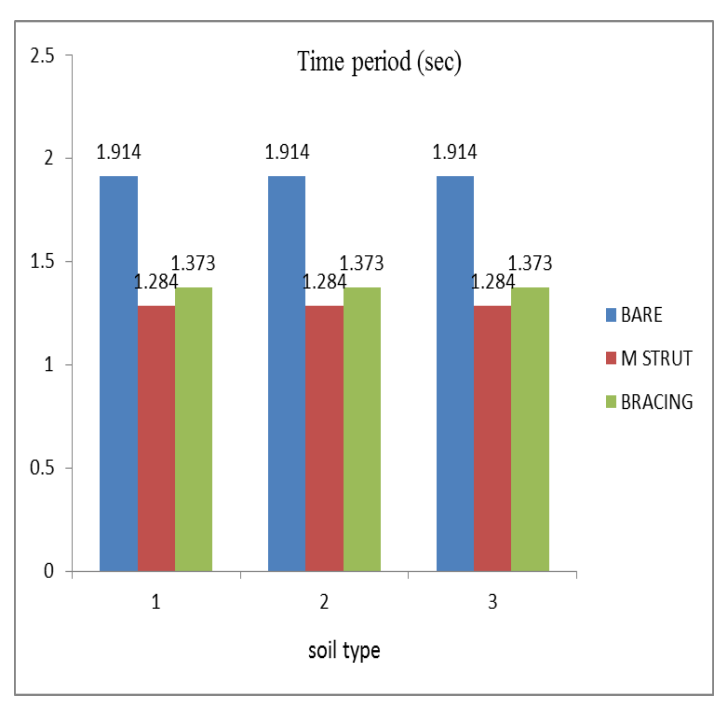

Figure 6: Time period (sec)

It can be clearly seen that as the mass of the structure increases time period of decreases. But for change in properties of the soil at the base of the structure do not affect the time period as it clearly seen from the table

Table 4: Frequency $(\mathrm{Hz})$

\begin{tabular}{|c|c|c|c|}
\hline \multirow{2}{*}{ Soil type } & \multicolumn{3}{|c|}{ Frequency $(\mathrm{Hz})$. } \\
\cline { 2 - 4 } & Bare & Bracing & Masonry strut \\
\hline Hard & 0.523 & 0.728 & 0.779 \\
\hline Medium & 0.523 & 0.728 & 0.779 \\
\hline Soft & 0.523 & 0.728 & 0.779 \\
\hline
\end{tabular}

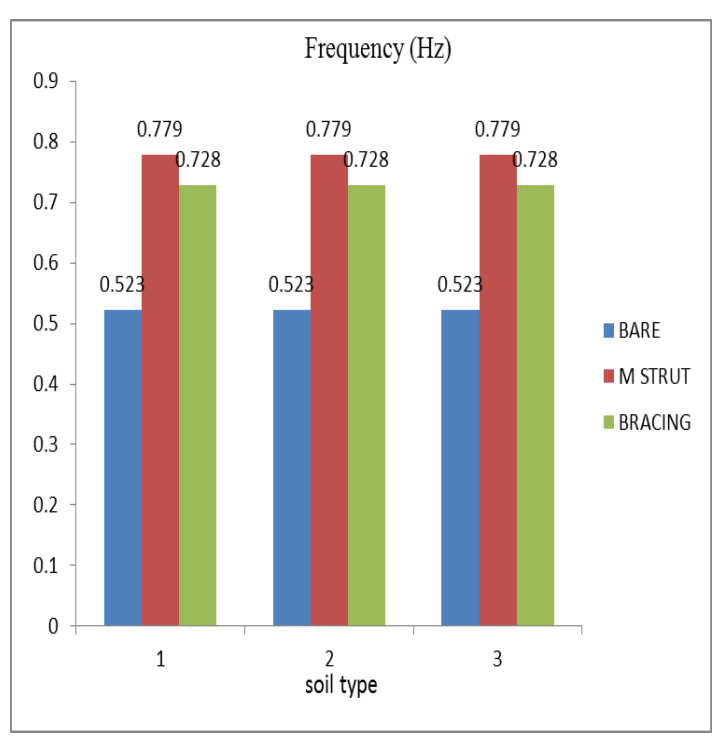

Figure 7: Frequency $(\mathrm{Hz})$

It can be clearly seen that as the stiffness of the structure increases frequency of the also increases, since stiffness is clearly related to the frequency. Change in properties of the soil at the base of the structure does not affect frequency as it seen from the table 
Table 5: Displacement in X Direction ( $\mathrm{mm})$

\begin{tabular}{|c|c|c|c|}
\hline \multirow{2}{*}{ Soil type } & \multicolumn{3}{|c|}{ Displacement in X Direction $(\mathrm{mm})$} \\
\cline { 2 - 4 } & Bare & Bracing & Masonry strut \\
\hline Hard & 94.6 & 43.5 & 35.9 \\
\hline Medium & 129.3 & 59.4 & 45.4 \\
\hline Soft & 135.3 & 65.4 & 47.8 \\
\hline
\end{tabular}

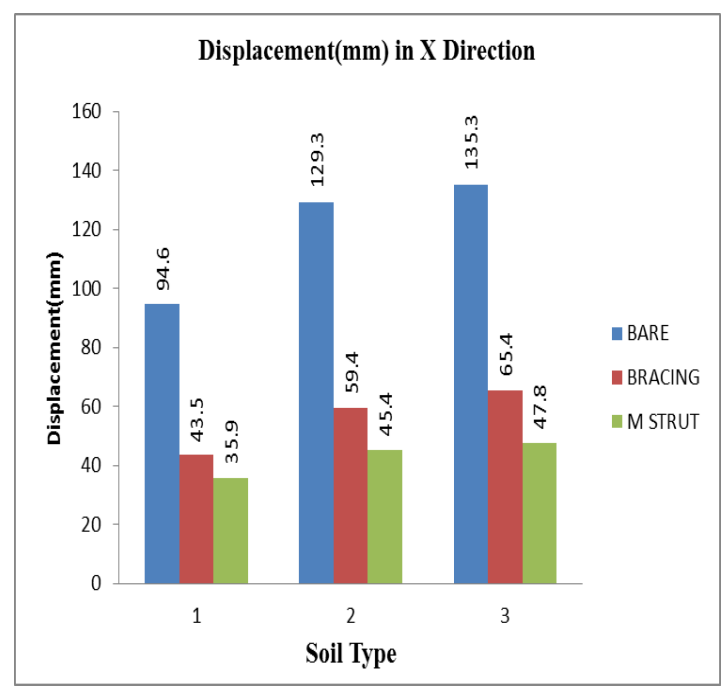

Figure 8: Displacement in X Direction (mm)

As the frequency of the structure increases displacement decreases. Hence for masonry in infill frame displacement is least compared to bare frame and braced frame. Since stiffness of the masonry infill is more it has more resistance to lateral load and hence displacement of the structure is minimised in both $\mathrm{X}-\mathrm{Y}$ directions as shown in tables.

Displacement of the structure decreases with the increase in stiffness of the structure. Hence stiffer soil displacement is least and for loose soil displacement is higher.

Table 6: Acceleration ( $\mathrm{mm} / \mathrm{sec} 2)$ in X Direction ( $\mathrm{mm})$

\begin{tabular}{|c|c|c|c|}
\hline \multirow{2}{*}{ Soil type } & \multicolumn{4}{|c|}{ Acceleration $(\mathrm{mm} / \mathrm{sec} 2)$ in X Direction $(\mathrm{mm})$} \\
\cline { 2 - 4 } & Bare & Bracing & Masonry strut \\
\hline Hard & 1020.09 & 1196.3 & 1887.64 \\
\hline Medium & 1494.22 & 1452.87 & 2284.08 \\
\hline Soft & 1522.48 & 1475.56 & 2366.92 \\
\hline
\end{tabular}

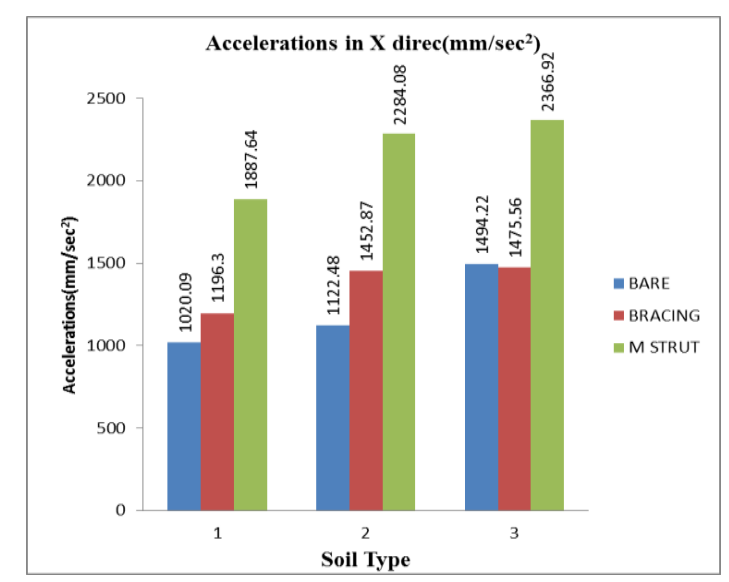

Figure 9: Acceleration (mm/sec2) in X Direction (mm)
Acceleration of the structure is highest for masonry infill structure and least for bare frame. Acceleration of the structure depends on ratio of stiffness to mass of the structure as the variation of mass is more than stiffness the acceleration is more for masonry infill. Also acceleration goes on increasing with decrease in stiffness of the soil and it can be clearly seen from the table.

Table 7: Storey Drift (mm) in X Direction

\begin{tabular}{|c|c|c|c|}
\hline \multirow{2}{*}{ Soil type } & \multicolumn{3}{|c|}{ Storey Drift $(\mathrm{mm})$ in X Direction } \\
\cline { 2 - 4 } & Bare & Bracing & Masonry strut \\
\hline Hard & 6.014 & 5.518 & 5.526 \\
\hline Medium & 8.202 & 7.512 & 6.486 \\
\hline Soft & 8.575 & 7.779 & 7.65 \\
\hline
\end{tabular}

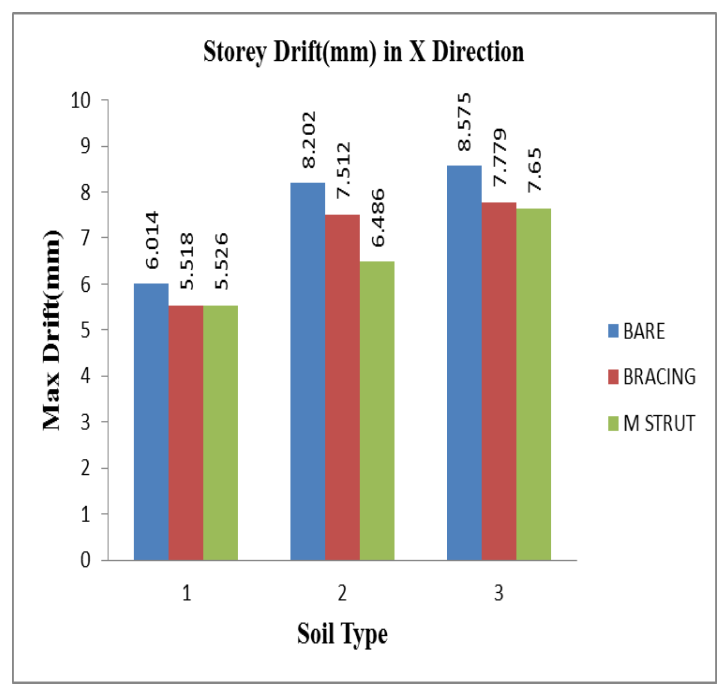

Figure 10: Storey Drift (mm) in X Direction

Storey drift of the structure is maximum at the lower stories of the structure. It is due to increase in the mass participation of the structure, but storey drift is more for bare frame and least for the masonry infill of the structure.

Since the stiffness of the structure is more for infill frame and it will try to resist the drift of the structure, similarly the drift of structure increases as stiffness of the soil decreases.

\section{CONCLUSION}

From the above results and discussion the following conclusions can be drawn;

1. Base shear of the structure increases with increase in seismic weight of the structure. Hence Base shear is high for masonry structures.

2. Frequency of the structure increases with rise in mass and rigidity of the structure. Hence for masonry infill frequency is highest and time period is least.

3. Displacement of the masonry infill is least due to increase in stiffness and mass of structure.

4. Acceleration of the masonry infill structure is more compared to that of other models.

5. Drift of the masonry structure is lesser than the base frame and steel braced frame due to high stiffness of the masonry wall and increased mass of the structure. 
6. It can be said from the result that as the stiffness and mass of the structure increases it is better to prefer for the earthquake loads.

7. All the responses of the building increases with decrease in the soil stiffness. Hence magnitude of all responses is high for the loose soil compared to that of stiff and hard soil.

8. Hence masonry infill structure are better performs for earthquake zones compared to that of steel braced structure at low cost due to increase in stiffness and mass of the structure.

9. But steel bracings can be used at the place where earthquakes occurrence is low and speed of the construction is more and cost is negotiable.

\section{SCOPE FOR FURTHER STUDIES}

The following further studies can also be done;

1. Can be done with different zones to know the response of the buildings

2. Can be done analysing with different methods such as Pushover analysis, Time history analysis and also Pdelta analysis.

3. Can be done comparing bare frame, shear wall and bracing with different soil stratum.

\section{REFERENCES}

[1]. S.M. Javid and S.F. Anwar, "Seismic Analysis and up gradation Of Structures Using Lateral Systems", International Journal of Engineering Sciences \& Research Technology ISSN: 2277-9655(I2OR), Vol. 4, No. 8, 2015.

[2]. A. Mulgund and J.G. Kori, "Seismic Evaluation Of Multi Storied Building With Infill Masonry", International Journal of Emerging Trends in Engineering and Development, Vol. 4, No. 5, 2015.

[3]. M. Mubeen, K. Nayaz Khan, M. Idrees Khan, "Seismic Analysis of Steel Frames with Eccentric Bracings using Pushover Analysis", International Journal of Advanced Technology in Engineering and Science, Vol. 3, No. 6, 2015.

[4]. B.D. Puneeth Kumar Naik, H.N. Manogna, N. Dharmesh and M. Hemalatha, "Seismic Response of A 3-Dimesional Analysis of Multi Storey RC Frame with Steel Bracing as Lateral Load Resisting Systems", International Journal of Science, Engineering and Technology ISSN 2319-8885 Vol. 4, No. 12, 2015.

[5]. S.K. Spoorthi and Dr. Jagadish G. Kori, "Effect of Soft Storey On Tall Buildings At Various Stories by Pushover Analysis", International journal of Engineering Research-Online A Peer Reviewed International Journal, Vol. 2,No. 3, 2014.

[6]. Prof. P.B. Kulkarni, R. Pooja, N. Agrawal, "linear Static Analysis Of Masonry Infilled RC Frame With \& Without Opening Including Open Ground Storey", International Journal of Innovative Research in Science, Engineering and Technology (ISO 3297: 2007 Certified Organization) Vol. 2, No. 8, 2013.

[7]. A.E. Hassaballa, F.M. Adam and M.A. Ismaeil, "Seismic Analysis of a Reinforced Concrete Building by Response Spectrum Method", IOSR Journal of Engineering (IOSRJEN), Vol. 3, No. 9, 2013.

[8]. D.R. Panchal and P.M. Marathe, "Comparative Study of R.C.C, Steel and Composite (G+30 Storey) Building", Institute Of Technology, Nirma University, Ahmedabad - 382, 481, Pp. 1-6, 2011.

[9]. J. Dorji and D.P. Thambiratnam, "Modelling and Analysis of Infilled Frame Structures Under Seismic Loads", The Open Construction and Building Technology Journal, Vol. 3, Pp. 119-126, 2009.

[10]. K.A. Korkmaz, F. Demir and M. Sivri, "Earthquake Assessment of RC Structures with Masonry Infill Walls", International Journal of Science \& Technology, Vol. 2, No. 2, Pp. 155-164, 2007.
[11]. L. Decanini, F. Mollaioli, A. Mura and R. Saragoni, "Seismic Performance Of Masonry Infilled RC Frames", 13th World Conference on Earthquake Engineering Vancouver, B.C., Canada August, No. 165, Pp. 1-6, 2004.

[12]. D. K. Bell and B.J. Davidson, "Evaluation of Earthquake Risk Buildings with Masonry Infill Panels", NZSEE Conference, 2001.

[13]. IS:456-2000, Plain and reinforced concrete- Code of practice (Fourth revision), Bureau of Indian Standards, Manak Bhavan, Bahadur Shah Zafar Marg, New Delhi, 2000.

[14]. IS: 1893-2002, Criteria for Earthquake Resistant Design of Structures, Part 1, Bureau of Indian Standards, New Delhi, India, 2002.

[15]. P. Agrawal and M. Shrikhande, "Earthquake Resistant Design of Structures", 2006. 